\title{
Encantador era mi barrio
}

\author{
Fidias López Valenzuela
}

\author{
LOM Ediciones, Colección Atenea, Luces para el Camino, \\ Santiago, 2007, 70 págs.
}

\section{María Ester Arancibia*}

Recibido: 25.08.2009

Aceptado: 26.10.2009

$$
* * *
$$

Fidias López Valenzuela, Geógrafo de Profesión, al igual que muchos otros colegas en el desarrollo laboral, nos vemos enfrentados al concepto de Barrio. Innumerables han sido los intentos por llegar a un consenso sobre su definición, incluso visto por distintos profesionales como Arquitectos, Paisajistas y Geógrafos, entre otros; pero sin duda, a través de este Libro "Encantador era mi Barrio" se logra la esencia de lo que significa la palabra Barrio.

El autor realiza una detallada descripción colmada de vivencias y sentimientos, sobre el Barrio Euclides de la Comuna de San Miguel. Inicia el relato con su nacimiento, pasando por la descripción de la vivienda en la cual residió junto a su grupo familiar, luego hace una observación panorámica de la gente que era vecina en el sector, describiendo cada una de las viviendas, los arrendatarios, vendedores ambulantes, almacenes, colegios, iglesia, teatro, cites, conventillos, fábricas, clubes deportivos, sindicatos, etc., siempre en torno a un eje central, la calle Euclides, mostrando con ello el modo de vida en un espacio urbano, en el cual se generan variadas interrelaciones, que hoy llamaríamos el Espacio Geográfico de Barrio.

En referencia al desarrollo de su vida laboral, el autor, un hombre de esfuerzo, hace la descripción desde el colegio hasta la universidad explicando cómo llega a estudiar Geografía en la Universidad de Chile, empujado a veces por la fuerza del deber más que la del querer, demostrando que con motivación y perseverancia se logran grades pasos profesionales, lo cual nunca hubiese sido posible sin el apoyo de su incondicional Ana María.

Son las historias de amor (madre/hijo, esposa/esposo, entre otras) un eje central en este libro, quedando en manifiesto que las ciudades, más allá de como se clasifiquen: barrio, cite, conventillo, entre otros, están ha-

\footnotetext{
*Universidad Bolivariana, Santiago, Chile. Email: marancibia@ubolivariana.cl
} 
bitadas por seres humanos, con sentimientos en común "la gente de mi barrio era gente sencilla, modesta, amable, amistosa, servicial y muy solidaria. Se ayudaba en los momentos difíciles, que eran muy frecuentes; todos se conocían, todos se saludaban...”, hoy en día, son estos gestos que la gente ha perdido.

En Santiago Centro, con el desarrollo de la mal denominada Renovación Urbana, que más bien es un Redesarrollo, se han destruido los barrios, y se practica otro tipo de vida muy al contraria a la del barrio; las personas hoy en día sólo miran hacia su vivienda, sus moradores se olvidaron de la vida en comunidad, lo que -como bien lo dice Fidias Lópezpodría ser algo heredado luego del 11 de Septiembre de 1973: “...la vida continuaba con todos sus sabores y esperanzas, el Barrio ya no pudo seguir siendo igual; no se conversaba en la esquinas, en la calle era peligroso hacerlo cuando se reunían más de tres personas...”.

Es de esperar entonces que tras el paso de los años, las nuevas generaciones que habitan estos espacios pudieran reconocer la convivencia en grupo, tanto en condominios como en comunidades de edificio, y formaran un nuevo concepto de barrio en donde predomine el bien común por sobre el interés individual. 